\title{
The Value of Inherited Deficiencies of Human Carbonic Anhydrase Isozymes in Understanding Their Cellular Roles ${ }^{a}$
}

\author{
RICHARD E. TASHIAN and DAVID HEWETT-EMMETT \\ Department of Human Genetics \\ University of Michigan Medical School \\ Ann Arbor, Michigan 48109 \\ SUSANNA J. DODGSON and ROBERT E. FORSTER, II \\ Department of Physiology \\ University of Pennsylvania School of Medicine \\ Philadelphia, Pennsylvania 19104 \\ WILLIAM S. SLY \\ Department of Pediatrics, Medicine and Genetics \\ Washington University School of Medicine \\ Division of Medical Genetics \\ St. Louis Children's Hospital \\ St. Louis, Missouri 63110
}

\section{INTRODUCTION}

There are probably at least five, genetically distinct isozymes of carbonic anhydrase present in mammals (for discussion see refs. 1-3). It is of course tempting to speculate that each of these isozymes has a special function in the particular cells where they are expressed. However, before we can ascertain such specific cellular or subcellular roles, we must first begin to identify more precisely the cellular localizations of the different isozymes. Utilizing immunohistochemical, or differential inhibition techniques, the histochemists have already made some good progress toward assigning specific isozymes to various cells and tissues (e.g., see some of the reports in this volume, ${ }^{4-11}$ and TABLE 1).

Considerable information has already been obtained concerning the physiological functions of carbonic anhydrase by studying the effects produced by the specific inhibition of carbonic anhydrase activity by aromatic or heterocyclic sulfonamides. For example, findings that the treatment of mammals with carbonic anhydrase inhibitors such as acetazolamide resulted in alterations in kidney function (bicarbonate reabsorption) and gastric acid secretion suggested some time ago that carbonic anhydrase was probably present in renal tubular cells and cells of the gastric mucosa (see ref. 12 for review). However, since both carbonic anhydrase isozymes, CA I and CA II, of mammals are strongly inhibited by sulfonamides, it was not possible to tell which isozyme(s) was present in the renal and gastric cells.

- This work was supported by United States Public Health Service grants GM 24681 (to R.E.T.), GM 31988 and GM 21096 (to W.S.S.) and HL 19737 (to R.E.F.). 
Another potentially useful approach to this problem would be to study the physiological effects produced in individuals where a genetic leison has resulted in a deficiency in one of the isozymes. In this report, we will discuss the effects of two mutations in humans that have resulted in the virtual absence of either CA I or CA II in the erythrocytes of individuals who are homozygous for the defective carbonic anhydrase gene.

\section{CELLULAR AND TISSUE DISTRIBUTION}

In order to determine the potential defects that might be produced by a carbonic anhydrase deficiency, it is essential to learn something about the tissue and cellular distribution of the carbonic anhydrase isozymes in humans and other mammals. In TABLE 1 are listed 14 tissues, organs or cells of mammals where one or more of the carbonic anhydrase isozymes has been identified either by immunohistochemical means or by actual purification. As can be seen, the CA II or CA II-like isozymes are found in almost all of the listed tissues and organs, whereas the CA I and CA III isozymes appear to have a somewhat more limited distribution. The apparent absence of CA I or CA III in some tissues should be viewed with caution, however, since these isozymes might be expressed (possibly at high levels) in only a small population of cells in a particular tissue and may have gone undetected by the technique employed. For the most part, the membranebound ${ }^{13-16}$ and mitochondrial ${ }^{17-19}$ carbonic anhydrases have not as yet been extensively characterized; nevertheless, in some cases, ${ }^{13,16,19}$ it appears that they are the products of genetic loci distinct from those coding for the CA I, CA II, and CA III isozymes. At this stage in our knowledge of the distribution of the carbonic anhydrase isozymes, it is especially important to utilize both activity and immunological methods on the same tissue or cellular samples in order to gain insights on the localization of those isozymes (e.g., membrane-bound forms) for which antisera are not yet available.

Although the physiological roles of the carbonic anhydrases in such tissues and cells as erythrocytes, the secretory epithelium of the stomach, and the luminal cells of the kidney tubules are understood to some extent, the function of carbonic anhydrase is not as well understood in cells from such organs or tissues as brain, lung, colon, eye, bone, muscle, and liver.

As already stated, an inherited deficiency in any one of the carbonic anhydrase isozymes could present us with a unique opportunity to examine the possible physiological role or roles of a particular isozyme. For example, if the CA I, CA II, and CA III isozymes in different tissues are each the products of single, separate loci, then one would predict that a defect in one of these genes might produce a defect in all of the cells in which that isozyme is normally expressed.

\section{DEFICIENCY OF CARBONIC ANHYDRASE I}

A deficiency of red cell CA I was described in a family originating from the Greek Island of Icaria. ${ }^{20}$ In this family, the individuals homozygous for the deficiency gene were asymptomatic. The hematological parameters and levels of CA II in the CA I-deficient red cells were within normal limits. ${ }^{21}$ The apparent lack of clinical abnormalities was not entirely unexpected, however, as it had been previously observed that the virtual absence of CA I from the red cells of pigtail macaques 
TABLE 1. Distribution of Soluble Carbonic Anhydrase Isozymes (Identified by Immunohistochemical or Purification Procedures) in Selected Tissues and Cells of Humans and Other Mammals ${ }^{a}$

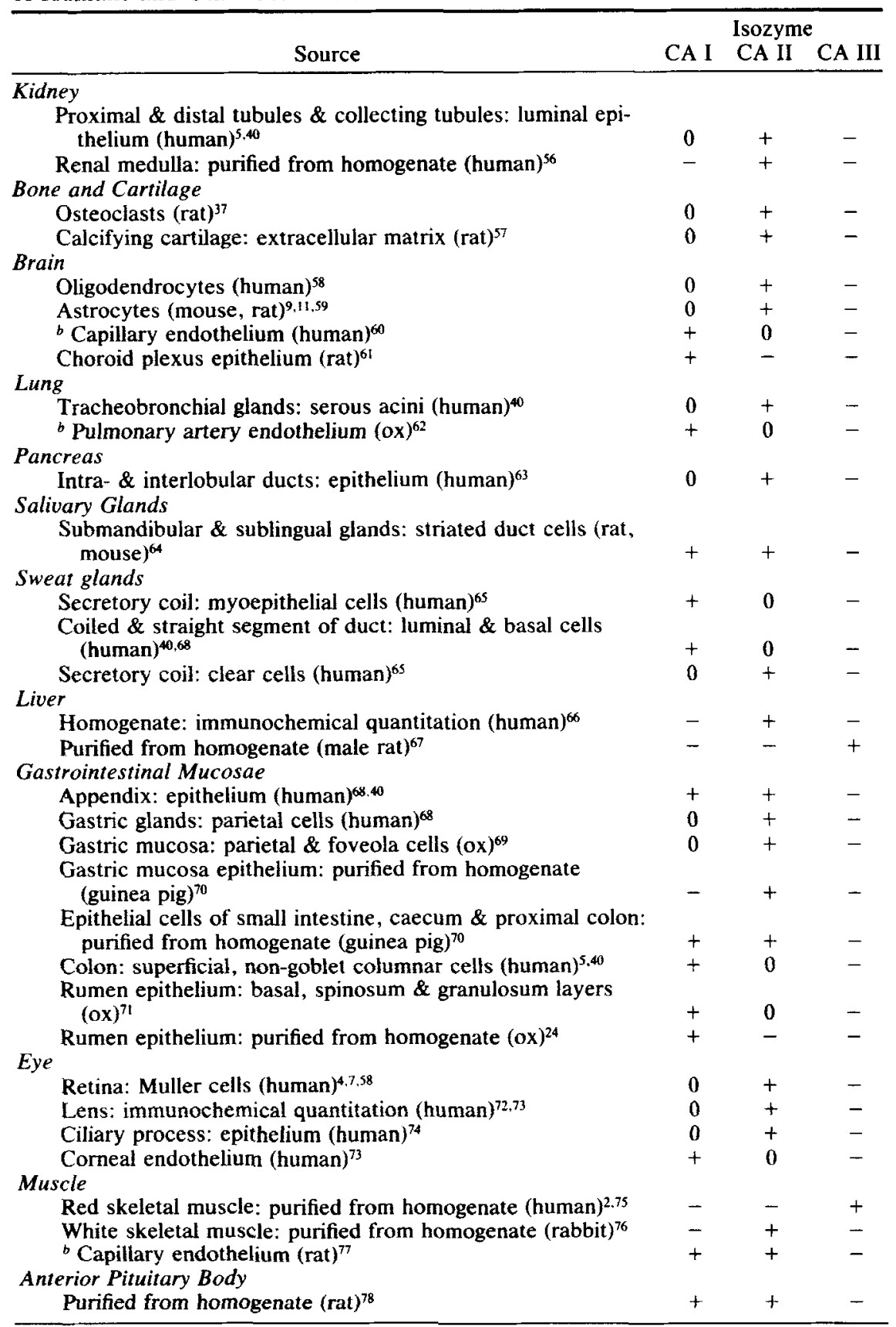


TABLE 1 (Continued)

\begin{tabular}{lccc}
\hline \multicolumn{1}{c}{ Source } & \multicolumn{3}{c}{ Isozyme } \\
\hline $\begin{array}{c}\text { Adipose cells } \\
\text { Peribronchial fat cells (mouse) } \\
\text { White fat cells: radioimmunoassay (rat) }\end{array}$ & CA I & CA II CA III \\
$\begin{array}{l}\text { Erythrocytes } \\
\text { Purified from hemolysate (human) }\end{array}$ & + & + & - \\
\hline
\end{tabular}

${ }^{a}$ Non-human species included only when no definitive information was available for that particular tissue or cell type in humans. Isozyme detected $(+)$, isozyme not detected or trace levels attributed to red cell contamination $(0)$, not tested $(-)$.

${ }^{b}$ Although the vascular endothelium can be classified as a separate organ (cf. ref. 80) it has been listed under the different organs or tissues because of the likelihood that its function could vary somewhat depending on the tissue in which the blood vessel is located.

(Macaca nemestrina) that were homozygous for a CA I deficiency gene, was seemingly without any obvious effect. ${ }^{22,23}$

Thus, although CA I or CA I-like isozymes have been identified from mammalian gastrointestinal mucosae, corneal endothelia, sweat glands, salivary glands, adipose cells, capillary endothelia, pituitary glands, and erythrocytes (TABLE 1), it has not been possible as yet to determine whether CA I is also deficient in cells, other than erythrocytes, of CA I-deficient individuals. Nevertheless, preliminary studies utilizing fluorescent antibody techniques have shown that cultured lymphocytes from CA I-deficient humans fluoresce as intensely as those from normal individuals (Tashian, unpublished work), ${ }^{24}$ suggesting that the deficiency of CA I in mature red cells may be due to the rapid degradation of a labile $\mathrm{CA} I$ or its mRNA during erythropoiesis, whereas this degradation may not be as severe in cells with different kinds or levels of proteolytic enzymes or ribonucleases. ${ }^{25}$ This possibility must, of course, await further analyses utilizing such quantitative techniques as the hybridization of CA I-mRNA with labeled CA I-CDNA probes.

The red cell CA I/CA II ratios were tested in the individuals from the CA Ideficient family ${ }^{20}$ shown in Figure 1 . The CA I/CA II values for the obligate heterozygotes of 2.9 and 3.8 are about half those from normal individuals (FIG. 2). In a survey made of red cell CA I concentrations in 3376 individuals in a Japanese population, Goriki et al $^{26}$ found 25 individuals with about half the normal CA I levels (i.e., $5.5 \pm 0.6 \mathrm{mg} / \mathrm{g} \mathrm{Hb}$ ). If these individuals are heterozygous for a CA I deficiency gene, then the frequency of this gene in this population would be $0.37 \%$. No homozygous CA I-deficient individuals were detected.

\section{DEFICIENCY OF CARBONIC ANHYDRASE II}

Since what appears to be the same CA II isozyme has now been reported from many tissues (TABLE 1), it would be expected that if these isozymes are the products of the same gene, that a mutation producing a defect in its expression might have wide-ranging physiological consequences.

An inherited deficiency of red cell CA II in humans has recently been reported where individuals homozygous for the deficiency gene are afflicted with a syndrome of osteopetrosis, with renal tubular acidosis and cerebral calcification. ${ }^{27}$ In 

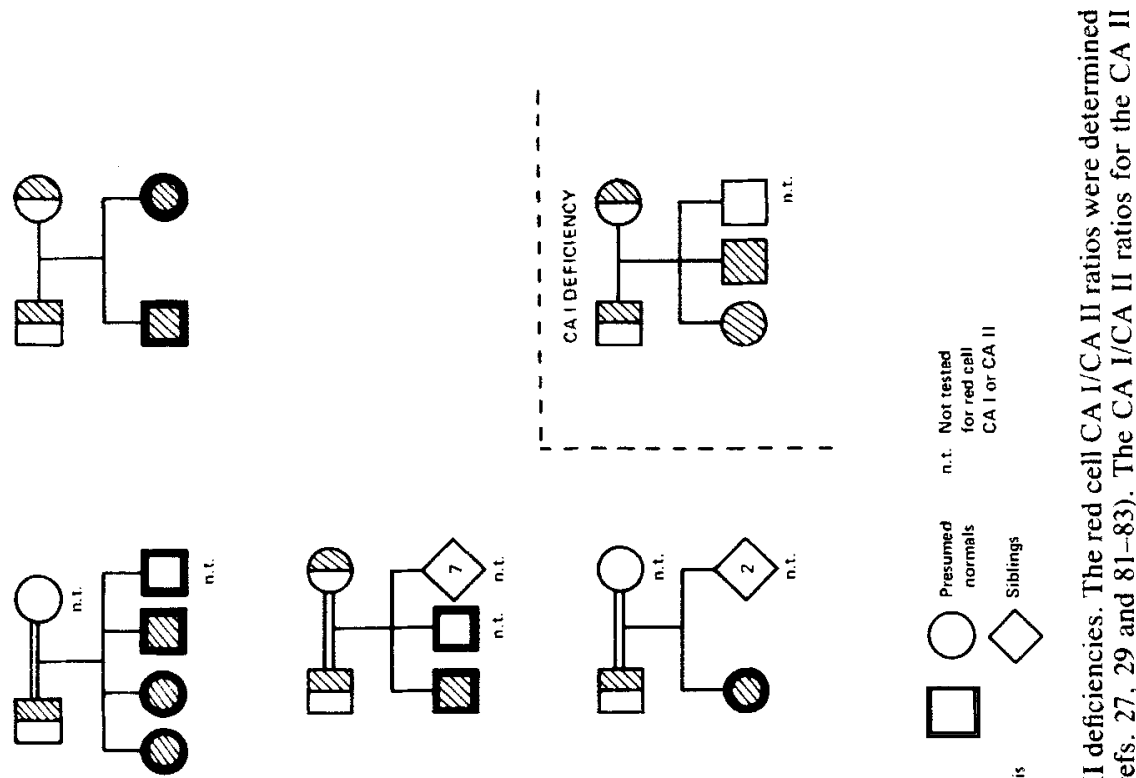

हैं 过 $\frac{1}{\infty}$

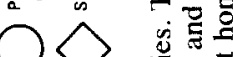

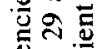

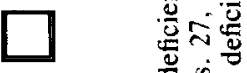
跣市

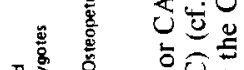

票究
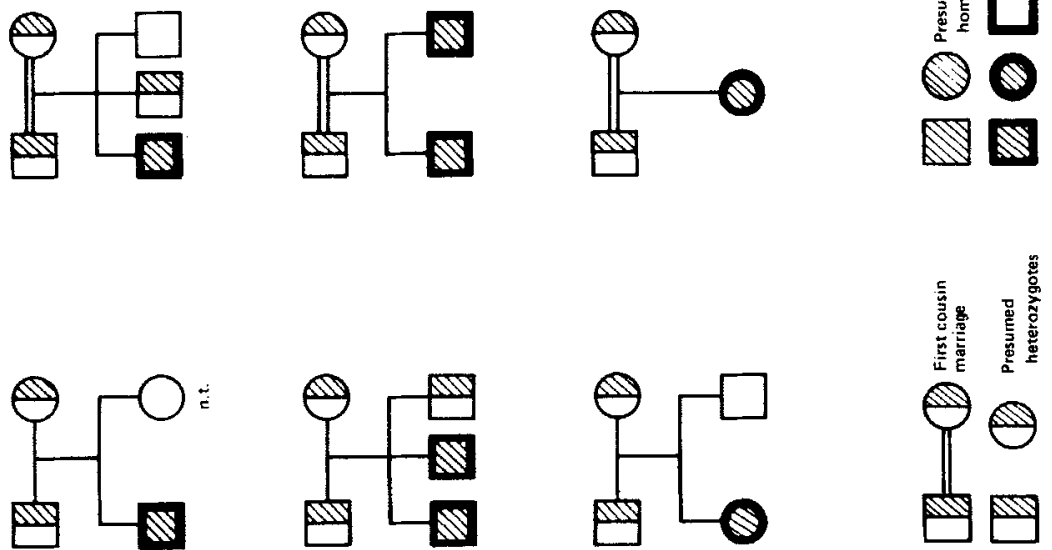

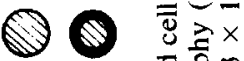
$\checkmark N$

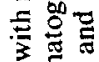
흥흐 要 㻤 政 \& 梷要 ¿․ $-i$ 젖 늘 
FIGURE 2. Histogram of individuals classified as normal ( $C A I I^{+} / C A$ $\left.\mathrm{II}^{+}\right)$, or as heterozygous $\left(\mathrm{CA} \mathrm{II}^{+} / \mathrm{CA}\right.$ $\mathrm{II}^{-}$) or homozygous $\left(\mathrm{CA} \mathrm{II}^{-} / \mathrm{CA} \mathrm{II}^{-}\right)$ for CA II deficiency genes $\left(\mathrm{CA} \mathrm{II}^{-}\right)$ on the basis of red cell CA I/CA II ratios as determined by HPLC (cf. refs. 27 and 29). Normals contain both controls and potential heterozygotes.

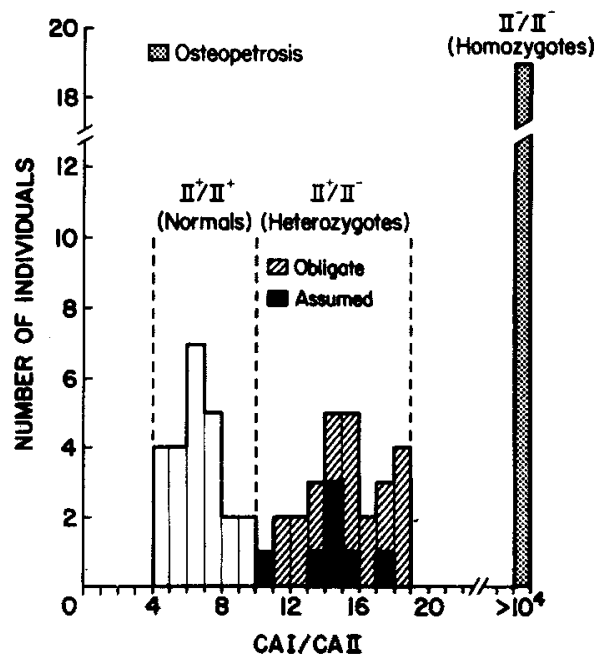

addition to the family from the United States which is of German and Italian ancestry, ${ }^{27,28} 10$ additional families have now been similarly diagnosed. The pedigrees of these families are shown in FIGURE 1. Three of the families are from the United States (two of which are of Hispanic ancestry and the other of Northern European ancestry), one is from Belgium, and six are of Arabian ancestry from North Africa, Saudi Arabia, and Kuwait. All but one of the Arabian families are the result of first cousin marriages; and in all probability, each parent carries the same CA II deficiency gene. Although osteopetrosis was found in all of the homozygous, CA II-deficient individuals, the severity of the renal tubular acidosis and degree of cerebral calcification were found to vary ${ }^{28}$ (W. S. Sly and M. P. Whyte, unpublished results).

The CA I/CA II ratios were determined by high performance liquid chromatography (HPLC) ${ }^{27,29}$ It was found that the obligate heterozygotes have values ranging from 11.5 to 18.8 , which are about twice the values from the presumed normal, unaffected controls of 5.0 to 7.6. The values for the CA II-deficient red cells of $>10^{4}$ represent minimal values. Since no CA II peaks could be detected by HPLC, the CA I levels were divided by the lowest measurable peaks in the elution patterns. The CA I/CA II values for the members of the families shown in Figure 1 , as well as those of the family from St. Louis originally described with the CA II deficiency syndrome, ${ }^{27}$ plus unaffected related and unrelated controls, are summarized in the histogram depicted in FIGURE 2. The lack of overlapping values between the normals and heterozygotes indicates that the CA I/CA II ratios can be used with reasonable confidence to detect carriers of the CA II deficiency gene. For comparative purposes, both presumed and obligate heterozygotes are delineated in Figure 2.

The frequency of a CA II deficiency gene appears to be quite low in the Japanese population. In blood samples from 3292 Japanese individuals, presumed heterozygotes for a CA II deficiency gene were detected in only two cases (Goriki et $a l .{ }^{26}$ ). 


\section{THE CA II DEFICIENCY SYNDROME}

\section{Bone Metabolism}

Since sulfonamide inhibition of carbonic anhydrase has been reported to interfere with bone resorption, ${ }^{30,31}$ it was suggested that carbonic anhydrase, mediated through parathyroid hormone (PTH), in bone cells may play an important role in bone metabolism. ${ }^{32-36}$ There is also histochemical evidence for the presence of $\mathrm{CA}$ II in rat osteoclasts. ${ }^{37}$ However, it was not until the findings that CA II deficiency is associated with an impairment of bone resorption ${ }^{27}$ that a physiological role for CA II was specifically implicated in osteoclasts.

\section{Renal Tubular Acidosis}

The renal tubular acidosis that has been reported for some of the CA II deficient individuals seems to have both a proximal and distal component. ${ }^{38}$ Since CA II is probably the major soluble isozyme of carbonic anhydrase in the human kidney, ${ }^{39}$ and specifically in the luminal cells of the proximal and distal tubules, as indicated by histochemical studies, ${ }^{40}$ then the absence or reduction of this isozyme in the luminal cells might be expected to interfere with bicarbonate reabsorption and hydrogen ion secretion, producing the "mixed" type of renal tubular acidosis reported in some CA II-deficient individuals. ${ }^{38}$

Another feature of interest is that we have learned something about the nature of the membrane-bound form of carbonic anhydrase, which has been described from the brush border and basolateral membrane of the luminal cells of the renal tubules in humans. ${ }^{14-16}$ Whether or not this bound carbonic anhydrase is CA II or a genetically distinct isozyme of carbonic anhydrase has been clarified somewhat by the finding that diuresis could be induced in two homozygous CA Il-deficient members of the St. Louis family ${ }^{27}$ after treatment with acetazolamide (W. S. Sly and M. P. Whyte, unpublished results). This finding suggests that the bound carbonic anhydrase is normal in the CA II-deficient individuals and that the uptake of $\mathrm{H}_{2} \mathrm{CO}_{3}$ is not impaired in the luminal cells. However, the reabsorption of $\mathrm{HCO}_{3}^{-}$is defective because of the presumed lack of soluble CA II in the luminal cells.

\section{Cerebral Calcification}

From histochemical analyses of mammalian brain tissue, carbonic anhydrase has been reported in oligodendrocytes, astrocytes, and choroid plexus epithelium (see TABLE 1), and it appears that in all cases this is the high-activity CA II isozyme. However, $50-60 \%$ of the carbonic anhydrase in rat brain homogenates is membrane bound. ${ }^{41,42}$ The interesting feature here is that even though the bound and soluble forms have similar molecular weights, and activities similar to the high-activity CA II isozyme of erythrocytes, they appear to be immunologically distinct from CA II and are synthesized on different polyribosomal complexes, ${ }^{43}$ suggesting that they may be products of different genes. It would, therefore, be extremely interesting to determine if one, both, or none of these CA II-like forms are absent or diminished in individuals who are homozygous for the CA II deficiency gene.

The basis for the cerebral calcification as well as the mental retardation in the CA II-deficient individuals remains an enigma. Although mental retardation in 
these individuals appears to be associated with some level of cerebral calcification, the opposite is not always true. That is, some CA II-deficient individuals whose intelligence was classified as "low normal" exhibited progressive (dense) basal ganglial calcification. ${ }^{28}$ Furthermore, none of the affected individuals in one family with inherited calcification of basal ganglia exhibited any evidence of mental retardation, osteopetrosis, or renal tubular acidosis. ${ }^{44}$ Carbonic anhydrase levels were not tested in the red cells of the affected individuals.

Basal ganglion calcification most often occurs in hypoparathyroidism. ${ }^{45,46}$ In the St. Louis family with CA II deficiency and osteopetrosis, the levels of PTH for all three affected sisters were reported to be in the normal range ${ }^{28}$ and could therefore be classified as pseudohypoparathyroidism. ${ }^{47}$ It thus appears to be most likely that the CA II deficiency in certain brain cells prevents the normal metabolism of calcium in these cells resulting in the calcification of certain areas of the brain.

\section{VARIABLE EFFECT OF THE CA II DEFICIENCY}

Why is there no apparent outward effect of the CA II deficiency in tissues other than bone, kidney, and brain where a high-activity CA II-like isozyme has been identified (see TABLE 1)? There are several possible explanations for this puzzling situation. First, alternative physiological mechanisms could substitute for the normal CA II function. Second, the mutation could render the CA II or its mRNA more labile to degradation, and the levels of CA II could vary from tissue to tissue where it is normally expressed depending on the turnover of CA II, or the type of proteolytic enzyme ${ }^{25}$ or ribonuclease present in a particular cell type. Third, there may be two or more CA I-like or CA II-like isozymes that are very similar or identical in structure but coded for by separate, closely linked genes that are differentially expressed in the cells of various tissues. Possible evidence for more than one CA II gene in the mouse has been discussed by Venta et al. ${ }^{3}$

As an extention of the first explanation given above, there is always the possibility that if both CA I and CA II are normally present in a particular cell, such as the red cell, CA I can take over the role of CA II. Although this may be the case for erythrocytes, as will be discussed next, it would be surprising if CA I could fulfill the function of CA II in all of the tissues where both isozymes are expressed.

The tissues of the eye are known to contain the CA II isozyme almost exclusively (see TABLE 1). Since serious clinical abnormalities of the eye have not been reported in CA II-deficient individuals, it was of interest to learn something about the levels of CA II in the eyes of an affected individual. The carbonic anhydrase inhibitor, acetazolamide (Diamox), is known to reduce intraocular pressure, ${ }^{48,49}$ and if CA II is absent or diminished in the cells of ocular tissues, one would expect no change in intraocular pressure with Diamox treatment. Two affected adults from the St. Louis family with the CA II deficiency gene ${ }^{27}$ were treated with Diamox and no change in intraocular pressure was detected (W. S. Sly, M. P. Whyte, and T. Krupin, unpublished results). These preliminary findings suggest that CA II may also be deficient in the eyes of these individuals.

The findings some years ago by Maren and his colleagues (see ref. 12 for review) that the treatment of dogs with high doses of carbonic anhydrase inhibitors for extensive periods of time did not produce any serious developmental or physiological abnormalities contrasts with the findings of clinical abnormalities reported in the CA II-deficient humans. ${ }^{27,28}$ One possible explanation is that the 
carbonic anhydrase inhibitors did not completely inhibit carbonic anhydrase activity, and that the residual activity was sufficient to maintain the normal functional and developmental roles of the carbonic anhydrases. On the other hand, Maren's early animal studies, ${ }^{12}$ as well as more recent studies on humans, ${ }^{50}$ suggest that alternative physiological mechanisms are able to substitute for the normal functions of the carbonic anhydrases.

\section{CARBONIC ANHYDRASE ACTIVITY IN CA II DEFICIENT ERYTHROCYTES}

The relative levels of the CA I, CA II, and CA III isozymes in red cells from adult humans are approximately $85: 13: 1$ respectively. ${ }^{54}$ The specific $\mathrm{CO}_{2}$ hydrase activity $/ K_{\mathrm{m}}$ of human $\mathrm{CA}$ II at $37^{\circ} \mathrm{C}$ and $\mathrm{pH} 7.1$, as determined by Wistrand ${ }^{51}$ (at physiological substrate concentrations) is about eight times higher than that of human CA I. No comparable activity data are available for human CA III at $37^{\circ} \mathrm{C}$; however, as Sanyal et al. ${ }^{52}$ have shown, the specific $\mathrm{CO}_{2}$ hydrase activity (at $\mathrm{pH}$ 7.5-7.6) of human CA III $\left(10.5^{\circ} \mathrm{C}\right)$ is about 35 times lower than that of human CA I $\left(13^{\circ} \mathrm{C}\right)$. Thus, we would expect very little contribution of CA III to the total carbonic anhydrase activity of human red cells. Because of the low specific activities of the CA I and CA III isozymes, and the fact that they are probably substantially inhibited by chloride ions present in red cell water, ${ }^{51.53}$ it is believed that these isozymes contribute only about $10 \%$ to the total carbonic anhydrase activity of the human red cell. ${ }^{51.53}$ It should be pointed out, however, that in erythrocytes from CA II-deficient individuals, the level of CA I appear to be slightly, but consistently, elevated, and the levels of CA III (which are normally about 90 times lower than CA I) were found by Carter et $a l .{ }^{54}$ to be doubled in erythrocytes of CA II-deficient individuals.

TABLE 2. Carbonic Anhydrase Activity in Intact CA II-Deficient and Control Erythrocytes

\begin{tabular}{|c|c|c|c|}
\hline \multirow[b]{2}{*}{ Genotype } & \multirow{2}{*}{$\begin{array}{l}\text { Number of } \\
\text { Individuals }\end{array}$} & \multicolumn{2}{|c|}{$\mathrm{k}_{\mathrm{enz}} \cdot\left[\mathrm{CO}_{2}\right]^{a}$} \\
\hline & & $25^{\circ} \mathrm{C}$ & $37^{\circ} \mathrm{C}$ \\
\hline $\mathrm{CA} \mathrm{II}^{+} / \mathrm{CA} \mathrm{II}{ }^{+}$(homozygote, normal) & 2 & $320 \pm 62(6)$ & $314 \pm 87(4)$ \\
\hline $\mathrm{CA} \mathrm{II}^{+} / \mathrm{CA} \mathrm{II}^{-}$(heterozygote) & 4 & $232 \pm 57(12)$ & \\
\hline CA II $-/ C A$ II $^{-}$(homozygote, deficient) & 2 & $71 \pm 10(6)$ & $173 \pm 36(14)$ \\
\hline
\end{tabular}

${ }^{a}\left[\mathrm{CO}_{2}\right]$ is the original substrate concentration; $\mathrm{k}_{\mathrm{enz}}$ formerly std $\mathrm{k}_{\mathrm{cat} .}{ }^{17}$ Units (mean $\pm \mathrm{SD}$ ) are $\mathrm{M} \mathrm{CO}_{2} \cdot \sec ^{-1} \mathrm{M}^{-1} \mathrm{Hb}_{4}$. Values in parentheses are number of assays performed. Intact red cells assayed in $24 \mathrm{mM} \mathrm{NaHCO} 3\left(2 \%\right.$ labeled with $\left.{ }^{18} \mathrm{O}\right)$. This corresponds to $1.987 \mathrm{mM}$ $\mathrm{CO}_{2}$ at $\mathbf{p H} 7.2$ which is the $\mathrm{pH}$ inside intact red cells in a pH 7.4 medium. The assay medium contained $0.125 \mathrm{M} \mathrm{NaCl}$ at $\mathrm{pH}$ 7.4. See references 17 and 55 for procedural details.

Because the red cells of CA II-deficient individuals appear to be functioning normally despite the fact that they are predicted to contain only about $10 \%$ of their normal carbonic anhydrase activity, we decided to determine the carbonic anhydrase activity in intact CA II-deficient red cells. These studies were carried out utilizing an ${ }^{18} \mathrm{O}$ exchange technique ${ }^{17,55}$ for determining carbonic anhydrase activity within intact cells (S. J. Dodgson and R. E. Forster unpublished results). Fresh erythrocytes were obtained from several members of the CA II-deficient family 
from St. Louis. ${ }^{27}$ These included four obligate heterozygotes and two CA IIdeficient homozygotes, and the results are shown in TABLE 2 . As can be seen, the carbonic anhydrase activity in the red cells of the homozygous CA II-deficient individuals increased from about $22 \%$ of those of the control values at $25^{\circ} \mathrm{C}$ to about $55 \%$ of controls at $37^{\circ} \mathrm{C}$. If the results of this in vitro study reflect the actual conditions within the CA II-deficient red cells in vivo, then it seems reasonably clear why the respiratory function of carbonic anhydrase in these cells does not seem to be impaired under unstressed conditions. The possible compensatory mechanisms underlying these findings must await further study. However, one possible explanation is that in some way the inhibition of $\mathrm{CA} I$ by chloride is "relaxed" in the CA II-deficient cells.

\section{SUMMARY}

Very little light has been shed on the role of the low-activity CA I isozyme in humans by studies on CA I-deficient individuals. On the other hand, CA IIdeficient individuals exhibit abnormalities of bone, kidney and brain, implicating a functional role for the high-activity CA II isozyme in cells from these tissues and organs. It also appears that the CA II-deficient red cell is capable of normal respiratory function under unstressed conditions. In addition, there is some preliminary evidence that those organs such as the eye which primarily contain the CA II isozyme, may be able to function effectively in the absence of CA II.

\section{ACKNOWLEDGMENTS}

We are especially grateful to Drs. Michael P. Whyte (St. Louis), Steve J. Funderburk (Los Angeles), Alan B. Grushkin (Philadelphia), P. Guibaud (Lyon), Nadia A. Sakati (Riyadh), M. Vainsel (Brussels), and Ms. Janet Salter (Montreal) for their indispensable roles in supplying us with the blood samples analyzed in this report and to Ms. Ya-Shiou $\mathrm{L}$. Yu for her expert assistance in preparing and typing them.

\section{REFERENCES}

1. Tashian, R. E., D. Hewett-Emmett \& M. Goodman. 1983. On the evolution and genetics of carbonic anhydrases I, II, and III. In Isozymes: Current Topics in Biological and Medical Research. M. C. Rattazzi, J. G. Scandalios, and G. S. Whitt, Eds. 7: 79-100. A. R. Liss. New York.

2. Hewett-Emmett, D., P. J. Hopkins, R. E. Tashian \& J. Czelusniak. 1984. Origins and molecular evolution of the carbonic anhydrase isozymes. Ann. N. Y. Acad. Sci. 429: 338-358. This volume.

3. Venta, P. J., J. C. Montgomery, K. Wiebauer, D. Hewett-Emmett \& R. E. TASHIAN. 1984. Organization of the mouse and human carbonic anhydrase II genes. Ann. N. Y. Acad. Sci. 429: 309-323. This volume.

4. Kumpulainen, T. 1984. Immunohistochemical localization of human carbonic anhydrase isozymes. Ann. N. Y. Acad. Sci. 429: 359-368. This volume.

5. LönNERHOLM, G. 1984. Histochemical localization of carbonic anhydrase in mammalian tissue. Ann. N. Y. Acad. Sci. 429: 369-381. This volume.

6. Spicer, S. S., M. A. Sens, R. A. Hennigar \& P. J. SToward. 1984. Implications of the immunohistochemical localization of carbonic anhydrase isozymes for their 
function in normal and pathological cells. Ann. N. Y. Acad. Sci. 429: 382-397. This volume.

7. Linser, P. \& A. A. Moscona. 1984. Variable CA II compartmentalization in vertebrate retina. Ann. N. Y. Acad. Sci. 429; 430-446. This volume.

8. Sapirstein, V. S., P. Strocchi \& J. M. Gilbert. 1984. Properties and function of brain carbonic anhydrase. Ann. N. Y. Acad. Sci. 429: 481-493. This volume.

9. Anderson, R. E., F. L. Engstrom \& D. M. Woodbury. 1984. Localization of carbonic anhydrase (CA) in the cerebrum and cerebellum of normal and audiogenic seizure mice. Ann. N. Y. Acad. Sci. 429: 502-504. This volume.

10. Delaunoy, S. P., D. Langui \& M. Sensendrenner. Influence of hormones and soluble factors from adult brain on the level of isozyme II of carbonic anhydrase (CA II) in oligodendrocytes present in rat glial primary culture. Poster presentation at the conference on Carbonic Anhydrase held by the New York Academy of Sciences, Sept., 1983.

11. Kimelberg, H. K. \& C. Richard. Carbonic anhydrase and $2^{\prime} 3^{\prime}$ cyclic nucleotide $3^{\prime}$ phosphohydrolase activity in perfused rat brain and rat brain primary cultures. Ann. N. Y. Acad. Sci. 429: 498-501. This volume.

12. Maren, T. H. 1967. Carbonic anhydrase chemistry, physiology and inhibition. Physiol. Rev. 47: 595-781.

13. Whitney, P. L. \& T. V. Briggle. Membrane-associated carbonic anhydrase purified from bovine lung. J. Biol. Chem. 257: 12056-12059.

14. Sanyal, G., N. I. Pessah \& T. H. Maren. 1981. Kinetics and inhibition of membrane-bound carbonic anhydrase from canine renal cortex. Biochem. Biophys. Acta 657: $128-137$.

15. MCKinley, D. N. \& P. L. WhitNEY. 1976. Particulate carbonic anhydrase in homogenates of human kidneys. Biochim. Biophys. Acta 445: 780-790.

16. Wistrand, P. J. 1984. Properties of membrane-bound carbonic anhydrase. Ann. N. Y. Acad. Sci. 429: 195-206. This volume.

17. Dodgson, S. J., R. E. Forster, B. T. Storey \& L. Mela. 1980. Mitochondrial carbonic anhydrase. Proc. Natl. Acad. Sci. USA 77: 5562-5566.

18. VinCENT, S. H. \& D. N. Sillverman. 1982. Carbonic anhydrase activity in mitochondria from rat liver. J. Biol. Chem. 257: 6850-6855.

19. Storey, B. T., S. J. Dodgson \& R. E. Forster, II. 1984. Mitochondrial carbonic anhydrase: The purified enzyme. Ann. N. Y. Acad. Sci. 429: 210-211. This volume.

20. Kendall, A. G. \& R. E. Tashian. 1977. Erythrocyte carbonic anhydrase I: Inherited deficiency in humans. Science 197: 471-472.

21. Tashian, R. E., A. G. Kendall \& N. D. Carter. 1980. Inherited variants of human red cell carbonic anhydrases. Hemoglobin 4: 635-651.

22. Tashian, R. E. \& N. D. Carter. 1976. Biochemical genetics of carbonic anhydrase. In Advances in Human Genetics. H. Harris and $\mathrm{K}$. Hirschhorn, Eds. 7: 1-55. Plenum Press, New York.

23. Ferrell, R. E., W. R. A. Osborne \& R. E. Tashian. 1981. Effect of metabolic acidosis on hydrogen ion excretion in a pigtail macaque with erythrocyte carbonic anhydrase I deficiency. Proc. Soc. Exp. Biol. Med. 168: 155-158.

24. TASHIAN, R. E. 1977. Evolution and regulation of the carbonic anhydrase isozymes. In Isozymes: Current Topics in Biological and Medical Research. M. C. Rattazzi, J. G. Scandalios, and G. S. Whitt, Eds. 2: 21-62. A. R. Liss. New York.

25. BUETLER, E. 1983. Selectivity of proteases as a basis for tissue distribution of enzymes in hereditary deficiencies. Proc. Natl. Acad. Sci. USA 80: 3767-3768.

26. GoRIKI, K., R. Hazama \& M. Yamakido. 1984. Human erythrocyte carbonic anhydrase deficiency in Japanese populations (Hiroshima, Nagasaki). Ann. N. Y. Acad. Sci. 429: 276. This volume.

27. Sly, W. S., D. Hewett-Emmett, M. P. Whyte, Y.-S. L. Yu \& R. E. Tashian. 1983. Carbonic anhydrase II deficiency identified as the primary defect in the autosomal recessive syndrome of osteopetrosis .with renal tubular acidosis and cerebral calcifcation. Proc. Natl. Acad. Sci. USA 80: 2752-2756.

28. Whyte, M. P., W. A. Murphy, M. D. Fallon, W. S. Sly, S. L. Teitelbaum, W. M. MCALISTER \& L. V. AvioLi. 1980. Osteopetrosis, renal tubular acidosis and basal ganglia calcification in three sisters. Am. J. Med. 69: 64-74. 
29. Hewetr-EMmetT, D. 1982. Analytical and preparative high performance liquid chromatography (HPLC) of the three human carbonic anhydrase isozymes and their tryptic peptides on reverse-phase columns. Fed. Proc. 41: 1385.

30. Dulce, H.-J., P. Siegmund, F. Körber \& E. Schütte. 1960. Zur Biochemie der Knockenauflösung, III. Über das vorkommen von Carbonanhydrase im Knocken. Hoppe-Seylers Z. Physiol. Chem. 320: 163-167.

31. Minkin, C. \& J. Jennings. 1972. Carbonic anhydrase and bone remodeling: Sulfonamide inhibition of bone resorption in organ culture. Science 176: 1031-1033.

32. FORSCHER, B. K. \& D. V. COHN, 1963. In vitro carbohydrate metabolism of bone: Effect of treatment of intact animals with parathyroid hormone. In Mechanisms of Hard Tissue Destruction. R. F. Sognnaes, Ed.: 577-588. Am. Assoc. Adv. Sci. Washington, D.C.

33. Körber, R. \& P. Siegmund, 1965. Versuche über Stoffwechselvorgänge bei der Auflösung von Knockenmineral. In Calcified Tissues. L. J. Richelle and M. J. Dallemagne, Eds.: 207-211. Collection des Collogues de l' université de Liège. Liège, Belgium.

34. Waite, L. C. \& A. D. Kenny. 1970. Acetazolamide and calcium metabolism in the rat. In Calcitonin. S. Taylor and G. V. Foster, Eds.: 442-450. William Heinemann Medical Books. London.

35. WAITE, L. C. 1972. Carbonic anhydrase inhibitors, parathyroid hormone and calcium metabolism. Endocrinology 91: 1160-1165.

36. Conaway, H. H., L. C. WaIte \& A. D. KenNy. 1973. Immobilization and bone mass in rats. Effects on parathyroidectomy and acetazolamide. Calc. Tiss. Res. 11: 323330.

37. VÄÄNÄNEN, H. K. \& E.-K. PARvinen. 1983. High activity isoenzyme of carbonic anhydrase in rat calvaria osteoclasts: immunohistochemical study. Histochemistry 78: 481-485.

38. Bourke, E., V. B. Delaney, N. Mosawi, P. Reary \& M. Leston. 1981. Renal tubular acidosis and osteopetrosis in siblings. Nephron 28: 268-272.

39. Wistrand, P. J., S. LiNdAHL \& T. WÅhlstrand. 1975. Human renal carbonic anhydrase. Purification and properties. Eur. J. Biochem. 57: 189-195.

40. SPICER, S. S., M. A. SENS \& R. E. TAShian. 1982. Immunocytochemical demonstration of carbonic anhydrase in human epithelial cells. J. Histochem. Cytochem. 30: 864-873.

41. Sapirstein, V. S., N. B. Lees \& M. C. Trachtenberg. 1978. Soluble and membrane bound carbonic anhydrase from rat. CNS: Regional development. J. Neurochem. 31: $283-287$.

42. Sapirstein, V. S., C. Flynn \& M. B. Lees. 1980. Development changes in carbonic anhydrase and adenylate cyclase in quaking mice. Brain Res. 185: 373-383.

43. Sapirstein, V. S., P. Strocchi, M. Weslowski \& J. M. Gilbert. 1983. Characterization and biosynthesis of soluble and membrane-bound carbonic anhydrase in brain. J. Neurochem. 40: 1251-1261.

44. Moskowitz, M. A., R. N. WINICKOFF \& E. R. HeINZ. 1971. Familial calcification of the basal ganglions: A metabolic and genetic study. N. Engl. J. Med. 285: 72-77.

45. BennetT, J. C., R. H. MAFFY \& H. L. SteinbaCh. The significance of bilateral basal ganglia calcification. Radiology 72: 368-378.

46. Babbit, D. P., T. TANG, J. DobBs \& R. BeRK. 1969. Idiopathic familial cerebrovascular ferrocalcinosis (Fahr's disease) and review of differential diagnosis of intracranial calcification in children. Am. J. Roentgenol. 105: 352-358.

47. Chase, L. R., G. L. Melson \& G. D. Aurbach. 1969. Pseudohypoparathyroidism: Defective excretion of $3^{\prime}, 5^{\prime}$-AMP in response to parathyroid hormone. J. Clin. Invest. 48: 1832-1844.

48. Friedenwald, J. S. 1955. Carbonic anhydrase inhibition and aqueous flow. Am. J. Opthalmol. 39: (suppl.): 59-64.

49. BECKER, B. 1955. The mechanism of the fall in intraocular pressure induced by the carbonic anhydrase inhibitor, Diamox. Am. J. Ophthalmol. 39(suppl.): 177184.

50. SWEnSON, E. R. \& T. H. MAREN. 1978. A quantitative analysis of $\mathrm{CO}_{2}$ transport at rest and during maximal exercise. Respir. Physiol. 35: 129-159. 
51. Wistrand, P. J. 1981. The importance of carbonic anhydrase B and C for the unloading of $\mathrm{CO}_{2}$ by the human erythrocyte. Acta Physiol. Scand. 113: 417-426.

52. Sanyal, G., E. R. Swenson, N. I. Pessah \& T. H. Maren. 1982. The carbon dioxide hydration activity of skeletal muscle carbonic anhydrase: Inhibition by sulfonamides and anions. Mol. Pharmacol. 22: 211-220.

53. Maren, T. H. \& E. O. Couto. 1979. The nature of anion inhibition of human red cell carbonic anhydrases. Arch. Biochem. Biophys. 196: 501-510.

54. Carter, N. D., R. Heath, R. J. Welty, D. Hewett-Emmett, S. Jeffery, A. Shiels \& R. E. TASHIAN. 1984. Red cells genetically deficient in CA II have elevated levels of a carbonic anhydrase indistinguishable from skeletal muscle CA III. Ann. N. Y. Acad. Sci. 429: 284-286. This volume.

55. Forster, R. E., II, S. J. Dodgson, B. T. Storey \& L. Lin. 1984. Measurement of carbonic anhydrase activity inside cells and subcellular particles. Ann. N. Y. Acad. Sci. 429: 415-429. This volume.

56. WÅHLstrand, T. \& P. J. Wistrand. 1980. Carbonic anhydrase $C$ in the human renal medulla. Uppsala J. Med. Sci. 85: 7-17.

57. KUMPUlAINEN, T. \& H. K. VÄÄNÄNEN. 1982. Immunohistochemical demonstration of extracellular carbonic anhydrase in epiphyseal growth cartilage. Calcif. Tiss. Int. 34: 428-430.

58. Kumpulainen, T., D. Dahl, L. Korhonen \& S. H. M. Nyström. 1983. Immunolabeling of carbonic anhydrase isozyme $\mathrm{C}$ and glial fibrillary acidic protein in paraffinembedded tissue sections of human brain and retina. J. Histochem. Cytochem. 7: 879-886.

59. Roussel, G., J. P. Delaunoy, J. L. Nussbaum \& P. Mandel. 1979. Demonstration of a specific localization of carbonic anhydrase $\mathrm{C}$ in glial cells of rat CNS by an immunohistochemical method. Brain Res. 160: 47-55.

60. Kumpulainen, T. \& L. K. KORHONEN. 1978. Immunohistochemical demonstration of carbonic anhydrase. Histochemistry 58: 83-192.

61. Masuzawa, T., T. Hasegawa, N. Nakahara, K. IIDa \& F. Sato. 1984. Localization of carbonic anhydrase activity in the rat choroid plexus epithelial cell. Ann. N. Y. Acad. Sci. 429: 405-407. This volume.

62. RYAN, U, S., P. L. WHITNEY \& J. W. RYAN. 1982. Localization of carbonic anhydrase on pulmonary artery endothelial cells in culture. J. Appl. Physiol. 53: 914-919.

63. Kumpulainen, T. \& P. Jal.ovaARA. 1981. Immunohistochemical localization of carbonic anhydrase isoenzymes in the human pancreas. Gastroenterology 80: 796-799.

64. Hennigar, R. A., B. A. Schulte \& S. S. Spicer. 1983. Immunolocalization of carbonic anhydrase isozymes in rat and mouse salivary and exorbital lacrimal glands. Anatomical Rec. 207: 605-614.

65. Briggman, J. V., R. E. Tashian \& S. S. SpICER. 1983. Immunohistochemical localization of carbonic anhydrase I and II in eccrine sweat glands from control subjects and patients with cystic fibrosis. Am. J. Pathol. 112: 250-257.

66. Funakoshi, S. \& H. F. DeUTSCH. 1971. Human carbonic anhydrases. VI. Levels of isozymes in old and young erythrocytes and in various tissues. J. Biol. Chem. 246: $1088-1092$.

67. Carter, N. D., D. Hewett-Emmett, S. Jeffery \& R. E. Tashian, 1981. Testosterone-induced sulfonamide-resistant carbonic anhydrase of rat liver is indistinguishable from skeletal muscle carbonic anhydrase III. FEBS Lett. 128: 114-118.

68. Kumpulainen, T. 1981. Human carbonic anhydrase isoenzyme C. Histochemistry 72: 425-431.

69. JONAS, L. 1982. Immunofluorescence histochemical detection of carbonic anhydrase in bovine stomach and kidney. Acta Histochem. 70: 43-53.

70. Carter, M. J. \& D. S. Parsons. 1972. The isoenzymes of carbonic anhydrase: Kinetic properties with particular reference to the functions in the intestinal tract. J. Physiol. London 220: 465-478.

71. GAlfi, P., Kutas, F. \& S. Neogrády. 1982. Immunohistochemical detection of bovine ruminal carbonic anhydrase isoenzyme. Histochemistry 74: 577-584.

72. Wistrand, P. J. \& S. N. Rao. 1968. Immunologic and kinetic properties of carbonic anhydrases from various tissues. Biochem. Biophys. Acta 154: 130-144. 
73. WISTRAND, P. J. 1984. The use of carbonic anhydrase inhibitors in ophthalmology. N. Y. Acad. Sci. 429:. This volume.

74. KUMPULAINEN, T. 1983. Immunohistochemical demonstration of carbonic anhydrase isozyme $C$ in the epithelium of the human ciliary process. Histochemistry 77: 281284.

75. Carter, N. D., S. Jeffery, A. Shiels, Y. Edwards, T. Tipler \& D. A. Hopkinson. 1979. Characterization of human carbonic anhydrase III from skeletal muscle. Biochem. Genet. 17: 837-854.

76. SIFFERT, W. \& G. GROs. 1982. Carbonic anhydrase C. in white-skeletal-muscle tissue. Biochem. J. 205: 559-566.

77. VÄÄÄNEN, H. K., T. Kumpulainen \& L. K. Korhonen. 1982. Carbonic anhydrase in the type I skeletal muscle fibers of the rat. J. Histochem. 30: 1109-1113.

78. Kimura, H. \& R. M. MacLeod. 1975. Evidence for existence of two isozymes of carbonic anhydrase in the anterior pituitary gland of female rats. J. Biol. Chem. 250: 1933-1938.

79. Carter, N., S. Jeffery \& A. Shiels. 1982. Immunoassay of carbonic anhydrase III in rat tissues. FEBS Lett. 139: 265-266.

80. Fishman, A. P., Ed. 1982. Endothelium. Ann. N. Y. Acad. Sci. 401: 1-274. 